\title{
Опыт регистрации вариаций уровня и физико-химических параметров подземных вод в пьезометрических скважинах, вызванных сильными землетрясениями (на примере Камчатки)
}

\author{
() 2016 г. Г.Н. Копылова, С.В. Болдина, А.А. Смирнов, Е.Г. Чубарова \\ Камчатский филиал Федерального исследовательского иентра "Единая Геофизическая служба РАН", \\ г. Петропавловск-Камчатский, Россия
}

\begin{abstract}
Дано описание аппаратурного комплекса для регистрации уровня, температуры, электропроводности подземной воды в скважинах и метеорологических параметров (атмосферное давление, температура воздуха) с периодичностью измерений от 5 мин до 1 ч производства ООО “Полином", г. Хабаровск. Оборудование установлено на скважинах Камчатки и используется в течение нескольких лет для регистрации изменений параметров подземных вод, вызванных землетрясениями. С использованием этой аппаратуры в скважинах Ю3-5 и E-1 зарегистрированы разнообразные вариации измеряемых параметров подземных вод в связи с сильными землетрясениями 2013 г., произошедшими 28 февраля, $M_{W}=6.8$ и 24 мая, $M_{W}=8.3$. Приводятся описание зарегистрированных вариаций и их систематизация с учетом механизмов сейсмического воздействия на состояние системы “скважина - водовмещающая порода".
\end{abstract}

Ключевые слова: скважина, уровень воды, электропроводность, аппаратурный комплекс, землетрясение, Камчатка.

PACS: 91.30.Px

\section{Введение}

Сильные землетрясения могут сопровождаться разнообразными вариациями уровней, температуры и химического состава поземных вод в скважинах. В работах [Копылова, 2006, 2010] такие изменения названы гидрогеосейсмическими вариациями и показано, что особенности их проявления определяются различными сейсмическими воздействиями на состояние системы “скважина - водовмещающая порода".

Изменения статического поля напряжений при образовании разрывов в очагах землетрясений и соответствующие вариации напряженно-деформированного состояния водовмещающих пород проявляются в косейсмических скачках повышения или понижения уровня воды в течение первых минут после вступления сейсмических волн. Динамическая деформация водовмещающих пород и сотрясения ствола скважины при прохождении сейсмических волн от сильных землетрясений также могут сопровождаться разнообразными ко- и постсейсмическими эффектами в изменениях уровней и химического состава подземных вод. Описание таких эффектов приводится в многочисленных работах, например в [Копылова, 2001, 2006; Копылова и др., 1994; Wang, Manga, 2010]. При их изучении основное внимание исследователей уделяется объяснению гидрогеодинамических и гидрогеохимических процессов их формирования и общей оценке воздействия сильных землетрясений на состояние флюидонасыщенной геологической среды. 
При проведении наблюдений в скважинах Камчатки и других сейсмоактивных регионов особый научный и практический интерес представляют изменения в состоянии подземных вод, проявляющиеся перед сильными землетрясениями (или гидрогеологические предвестники), в связи с возможностью их использования для прогнозирования сильных землетрясений и уточнения времени таких событий [Копьлова, 2001, 2006а,б, 2010; Копьлова, Болдина, 2012; Копьлова и др., 1994; Wang, Manga, 2010].

Камчатским филиалом Федерального исследовательского центра "Единая Геофизическая служба РАН” (КФ ФИЦ ЕГС РАН) проводятся наблюдения в скважинах за изменениями физико-химических параметров подземных вод с целью поиска предвестников землетрясений и других эффектов сейсмичности. При использовании данных наблюдений в скважинах в сейсмопрогностических целях и для обеспечения надежной регистрации эффектов от сейсмических волн необходимо применять надежную прецизионную измерительную аппаратуру, позволяющую проводить мониторинг в полевых условиях в режиме, близком к реальному времени. В КФ ФИЦ ЕГС РАН при проведении наблюдений в пьезометрических скважинах используются аппаратурные комплексы, созданные в ООО “Полином”, г. Хабаровск, обеспечивающие синхронные измерения уровня, температуры и электропроводности воды, а также метеорологических параметров - атмосферного давления и температуры воздуха, с периодичностью опроса от 5 мин до одного часа [Калинов и др., 2012].

В настоящей работе с использованием опубликованных материалов [Калинов $u$ $\partial p$., 2000, 2012; Римлянд и др., 2000] приводятся технические характеристики основных элементов измерительного комплекса, а также примеры гидрогеосейсмических вариаций уровня, температуры и электропроводности воды, зарегистрированные в скважинах Ю3-5 (глубина 800 м, уровень на глубине 1 м ниже оголовка) и Е-1 (глубина 665 м, уровень на глубине 27 м) в связи с сильными землетрясениями, произошедшими в 2013 г. 28 марта, $M_{W}=6.8$ и 24 мая, $M_{W}=8.3$ (рис. 1, таблица). Данные о строении скважин и локальных гидрогеологических условиях приводятся в [Копьлова, 2001, 2006а], a также на сайте КФ ФИЦ ЕГС РАН по адресам http://emsd.ru/lgi/places/e1 и http://emsd.ru/lgi/places/uz5.

Измерения гидрогеологических и метеорологических параметров проводятся с интервалом 5 мин. Передача данных в КФ ФИЦ ЕГС РАН осуществляется один раз в час, обработка данных проводится в лаборатории геофизических исследований КФ ФИЦ ЕГС РАН ежедневно. Результаты обработки в виде графиков временных рядов изменений уровня воды (исходных и очищенных от влияния факторов-помех) представляются ежедневно на сайте КФ ФИЦЕГС РАН по адресу http:/emsd.ru/ lgi/observations.

Параметры сильных камчатских землетрясений 2013 г. [Сильные..., 2014]

\begin{tabular}{|c|c|c|c|c|c|c|c|c|c|c|c|c|}
\hline \multicolumn{5}{|c|}{ Гипоцентр } & \multicolumn{6}{|c|}{ Энергетический класс/магнитуда } & \multirow{3}{*}{$\begin{array}{l}R, \\
\text { км }\end{array}$} & \multirow{3}{*}{$\begin{array}{c}\text { Балл } \\
\text { MSK- } \\
64\end{array}$} \\
\hline \multirow{2}{*}{$\begin{array}{c}\text { Дата } \\
\text { дд.мм.гггг }\end{array}$} & \multirow{2}{*}{$\begin{array}{c}\text { Время } \\
\text { чч:мм:сс }\end{array}$} & \multirow[t]{2}{*}{ с.ш. } & \multirow[t]{2}{*}{ в.д. } & \multirow{2}{*}{$\begin{array}{l}H, \\
\text { км }\end{array}$} & \multicolumn{3}{|c|}{$\begin{array}{c}\text { КФ ФИЦ ЕГС } \\
\text { РАН }\end{array}$} & \multirow{2}{*}{$\begin{array}{c}\begin{array}{c}\text { Global } \\
\text { CMT }\end{array} \\
M_{W} \\
\end{array}$} & \multicolumn{2}{|c|}{$\begin{array}{c}\text { NEIC } \\
\text { (USGS) }\end{array}$} & & \\
\hline & & & & & $K_{S}$ & $M L$ & $M_{C}$ & & $m b$ & $M_{W}$ & & \\
\hline 28.02 .2013 г. & $14: 05: 48$ & 50.67 & 157.77 & 61 & 15.2 & 6.9 & 6.6 & 6.8 & 6.4 & 6.9 & 265 & $4-5$ \\
\hline 24.05.2013 г. & $05: 44: 47$ & 54.76 & 153.79 & 630 & 17.0 & 7.8 & 8.3 & 8.3 & 7.5 & 8.3 & 370 & $4-5$ \\
\hline
\end{tabular}


a
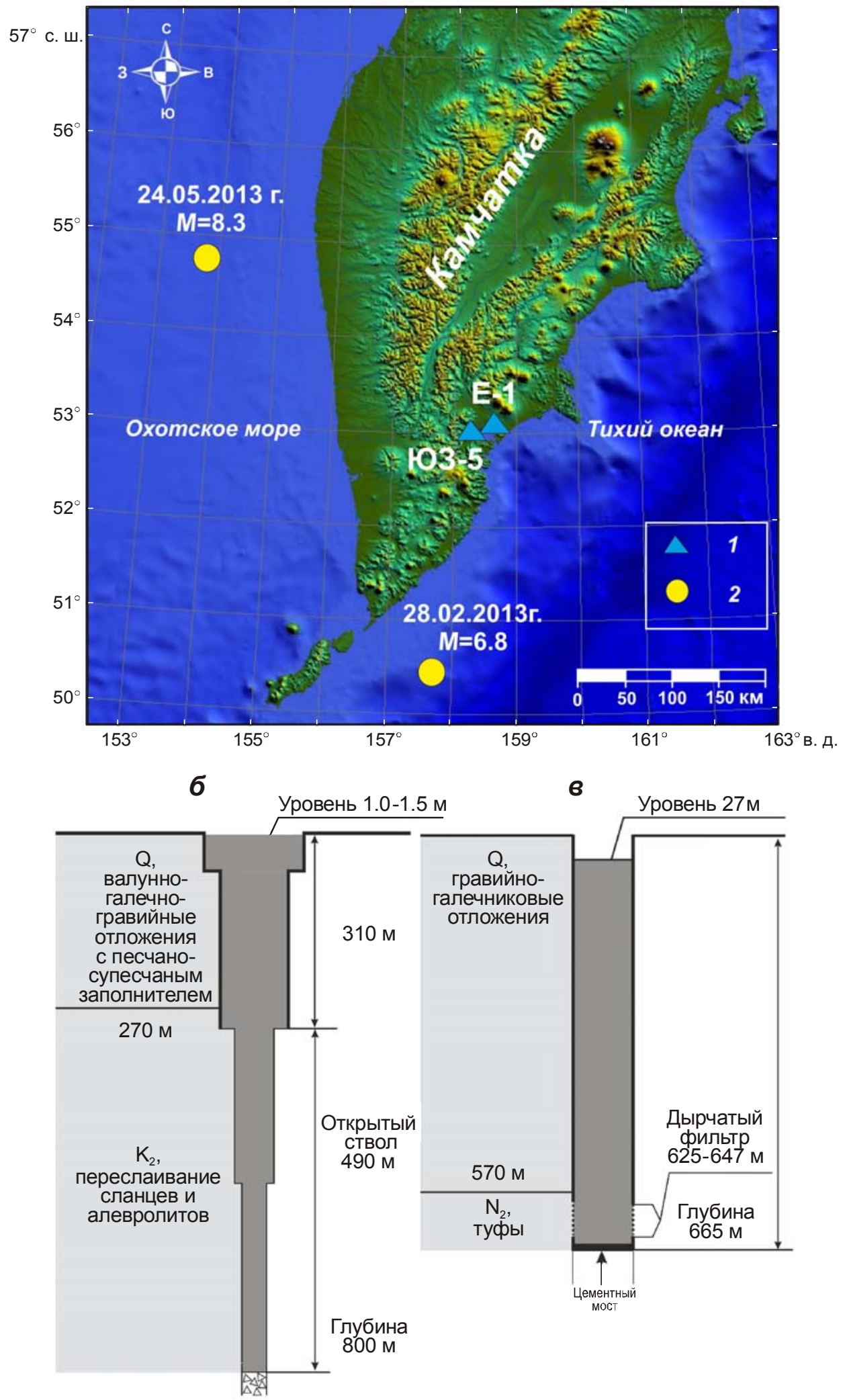

Рис. 1. Схемы размещения наблюдательных скважин и эпицентров сильных землетрясений 2013 г. (таблица) (a); строения скважин Ю3-5 (б) и Е-1 (в) с характеристикой водовмещающих пород. 1 - скважина; 2 - эпицентр землетрясения 


\section{Аппаратура}

В 2013 г. наблюдения на скважинах Ю3-5 и Е-1 проводились с использованием аппаратурного комплекса Кедр-ДМ-У (ООО “Полином”, г. Хабаровск) с телеметрической передачей данных в КФ ФИЦ ЕГС РАН по каналам сотовой связи общего пользования [Кедр ДМ..., 2007; Калинов и др., 2012].

В состав Кедр-ДМ-У входят высокочувствительный ультразвуковой датчик уровня воды (уровнемер), позволяющий регистрировать изменения уровня воды с точностью \pm 0.1 мм, и глубинный зонд для измерений электропроводности и температуры подземной воды. Датчики атмосферного давления и температуры воздуха входят в состав блока регистрации БСИ 300, который устанавливается над оголовком скважины. Схема установки измерительного комплекса на скважинах приводится на рис. 2.

a

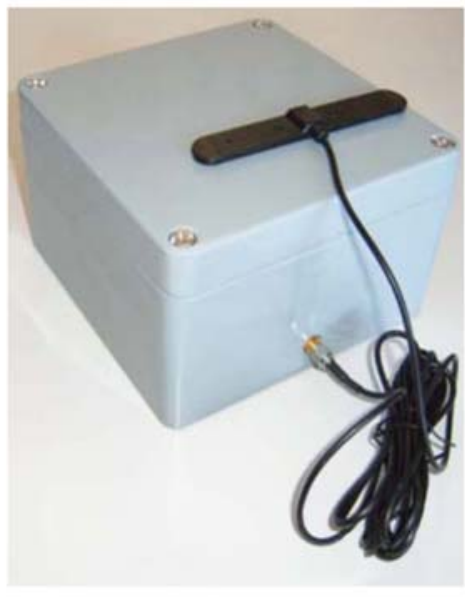

6

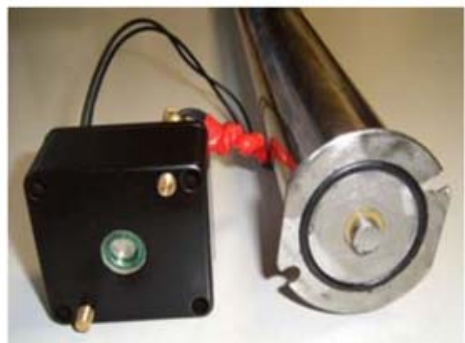

(1)
6

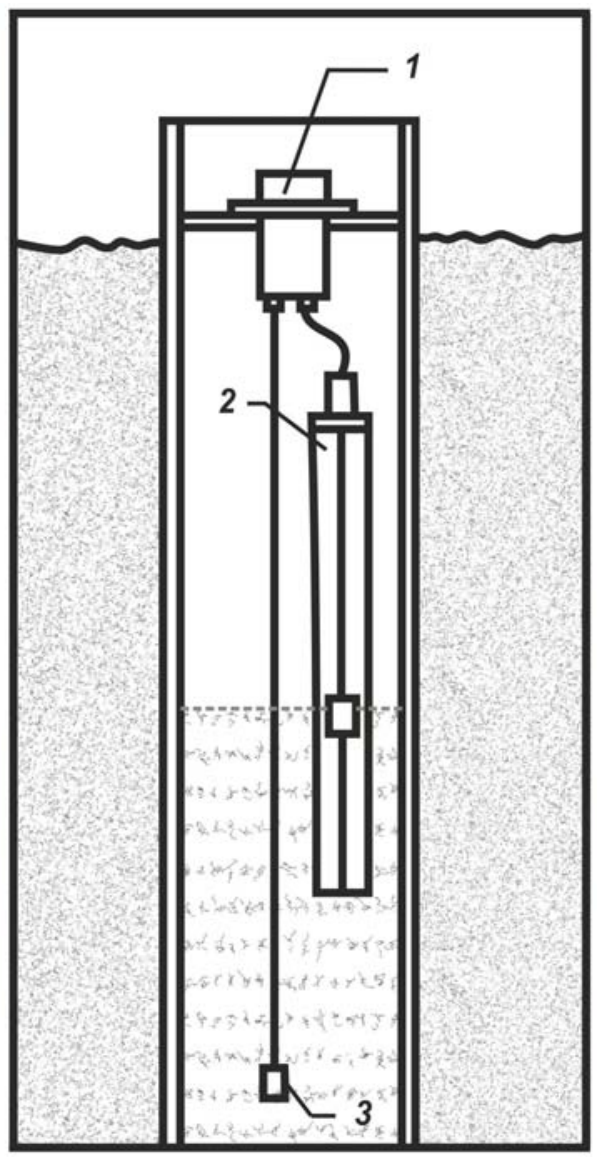

2

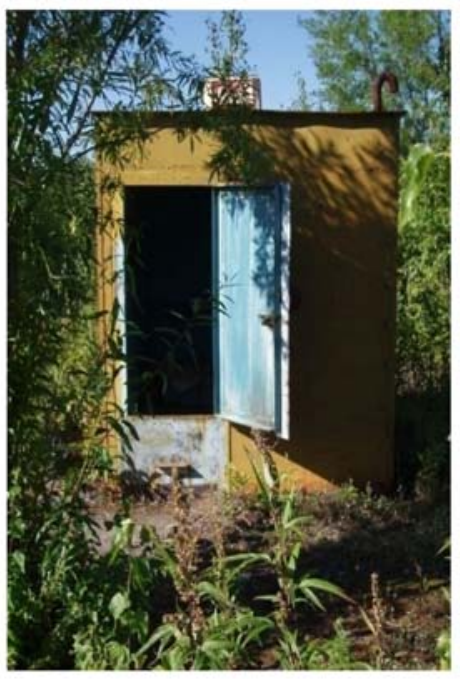

$\partial$

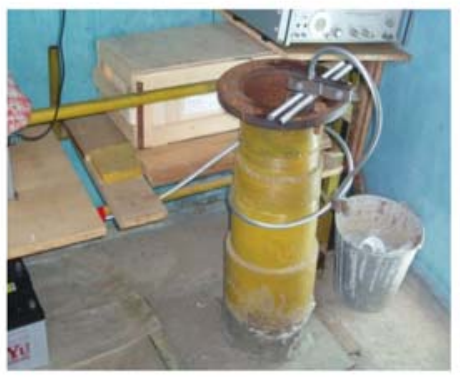

Рис. 2. Компоненты измерительного комплекса Кедр-ДМ-У и схема его установки в скважине: $a$ - регистратор БСИ 300 с подключенной GSM - антенной; $\sigma$ - ультразвуковой уровнемер с преобразователем; В - схема установки оборудования в скважине: 1 - БСИ 300 - блок сбора информации, включающий датчики атмосферного давления и температуры воздуха; 2 - ультразвуковой датчик уровня воды; 3 - глубинный зонд, оборудованный датчиками температуры и электропроводности воды; г - железобетонное защитное сооружение над оголовком скважины; $\partial$ - оголовок скважины Е-1

Основным блоком измерительного комплекса является система регистрации уровня воды в стволе скважины. В КФ ФИЦ ЕГС РАН для уровнемерных наблюдений использовались модификации Кедр-А2-У и Кедр-ДМ-У, в которых измерения уровня воды осуществляются ультразвуковым уровнемером (рис. 2, б, в). Индексы А и ДМ 
обозначают способы хранения и передачи информации с наблюдательных скважин. В Кедр-А2 результаты измерений хранятся в переносном модуле энергонезависимой памяти; передача информации выполняется посредством смены накопителя данных. Кедр-ДМ имеет телеметрический канал на основе сотовой или спутниковой связи.

Ультразвуковой скважинный уровнемер [Калинов и др., 2000, 2012; Римлянд и др., 2000]. Метод определения уровня воды основывается на измерении времени распространения ультразвукового импульса (УЗИ) в вертикальном звукопроводе. Звукопровод представляет собой тонкий металлический стержень. При этом УЗИ формируется непосредственно на границе раздела жидкость-воздух [Калинов и др., 2000].

Скважинный уровнемер (рис. 2,6, в) состоит из корпуса, представленного защитной трубой диаметром 51 мм и длиной до 3 м; вертикального стержня-звукопровода, натянутого в центре трубы; поплавка-излучателя УЗИ, коаксиально охватывающего стержень и свободно перемещающегося вдоль него; блока питания, синхронизации и приема УЗИ, укрепленного на верхнем конце стержня; эталонного излучателя УЗИ, укрепленного на нижнем конце стержня. Уровнемер опускается на специальном тросе в скважину. На поверхности земли над оголовком скважины расположен блок сбора информации БСИ (логгер) (рис. 2, $a, b)$, связь с которым осуществляется по кабелю.

Возбуждение УЗИ производится пьезокерамикой в виде кольца, коаксиально охватывающего звукопровод. На пьезокерамику синхронно с запуском счетчика времени подается электрический импульс, который вырабатывается специальной электронной схемой, расположенной в поплавке. Для подачи питания и обеспечения синхронизации процесса излучения акустического импульса была разработана специальная система на основе индукционного метода [Калинов и др., 2000, 2012]. В качестве первичного витка трансформатора используются металлический стержень - звукопровод и защитная труба. Вторичная обмотка трансформатора расположена внутри корпуса поплавка.

Индуцированный сигнал разделяется во времени на сигнал питания, обеспечивающий зарядку накопительного конденсатора, и импульс синхронизации. Включение питания излучателя происходит с задержкой по времени по отношению к сигналу зарядки и длится 100 мкс.

На рис. 3, а представлена функциональная схема питания и синхронизации ультразвукового излучателя [Калинов и др., 2012]. Блоки 1-3 расположены на неподвижном основании, блоки 4-11- внутри поплавка.

a

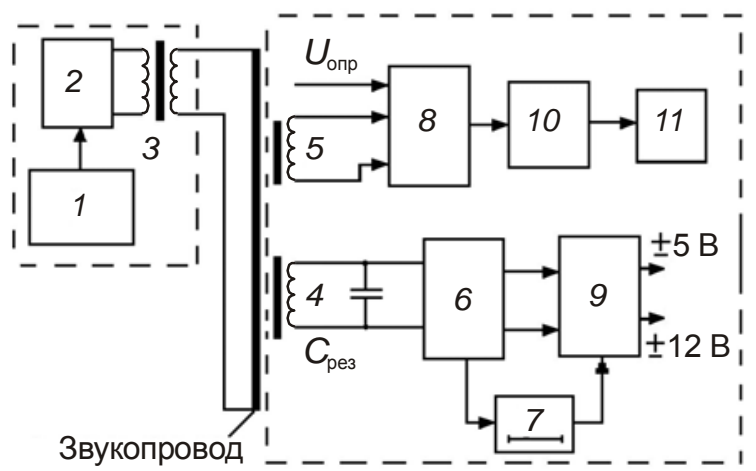

6

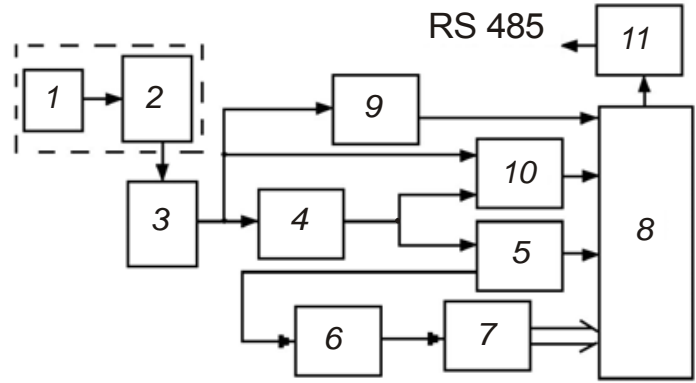

Рис. 3. Функциональная схема скважинного уровнемера по [Калинов и дp., 2012]: $a$ - акустического излучателя; $\sigma$ - приема акустических сигналов (пояснения см. в тексте)

Микропроцессор 1 формирует необходимые для работы сигналы. На вход смесителя 2 поступают сигналы частоты зарядки и синхронизации. Выход смесителя 2 под- 
ключен к понижающему трансформатору 3. Вторичная обмотка трансформатора питания 4 и конденсатор $C_{\text {рез }}$ образуют резонансный контур, что позволяет получить высокое напряжение на выходе детектора напряжения 6. Зарядка накопительных конденсаторов блока 6 производится в течение 20 мс током частотой 16 кГц. Микропроцессор вырабатывает импульс синхронизации (СИ) через определенное время после окончания видеоимпульса частоты зарядки (рис. 3). После прекращения сигнала зарядки, определяемого нормированной задержкой, схема 7 (рис. 3, a) вырабатывает строб-импульс длительностью 0.1 мс. Во время его действия блок 9 обеспечивает питание сдвоенного фазового обнаружителя синхроимпульса 8 и блока 10 , формирующего электрический импульс для возбуждения пьезокерамики 11. Фазовый обнаружитель 8 регистрирует первый переход напряжения СИ через нулевой уровень. При этом момент начала формирования акустического импульса не зависит от амплитуды СИ и параметров первичного витка. Конструкция и работа фазового обнаружителя представлена в работе [ $\mathrm{Ka}$ линов и др., 2009]. Электронная схема поплавка, включая трансформаторы питания и синхронизации, размещается на печатной плате диаметром 31 мм, весом 7.5 г.

Основными факторами, влияющими на работу уровнемера, являются точность регистрации момента прихода УЗИ и измерение времени его распространения. На рис. 3, б представлена функциональная схема блока приема и измерения времени прихода УЗИ. При перемещении акустического излучателя (поплавка) вдоль волновода амплитуда и форма переднего фронта акустического сигнала существенно изменяются. В уровнемерах Кедр-А2-У и Кедр-ДМ-У реализован фазовый способ регистрации УЗИ, работа которого аналогична регистрации СИ поплавком-излучателем [Калинов и дp., 2009]. Началом отсчета для времени распространения УЗИ от излучателя до приемника является СИ, запускающий генератор УЗИ в поплавке. УЗИ, сформированный излучателем, распространяется по стержню волновода и поступает на пьезоприемник 1 (рис. 3, б) и далее на вход малошумящего усилителя 2. Элементы 1 и 2 конструктивно совмещены и установлены на торце волновода. Далее сигнал проходит через ФВЧ 2-го порядка 3 , усилитель 4 и ограничитель амплитуды 5 . Блок схемы 6 обеспечивают фазовый прием первой полуволны импульса. На выходе схемы 6 формируется импульс, который оцифровывается счетчиком 7. Микропроцессор 8 считывает состояние счетчика.

После окончания измерительного импульса микропроцессор вычисляет расстояние от излучателя до преобразователя. При работе схемы учитывается соотношение сигнал/шум [Калинов и дp., 2009]. Это делается с помощью детектора шума 9 и пикового детектора 10. Посредством встроенного интерфейса RS 485 (11) данные по линии связи передаются в микропроцессор блока сбора информации.

На точность измерения уровня воды влияют температура, линейное расширение металлического волновода, дрейф частоты кварцевого генератора и пр. С целью исключения помех используется метод измерения уровня с встроенной автоматической калибровкой [Калинов и др., 2000, 2012].

Ультразвуковой скважинный уровнемер имеет следующие метрологические характеристики: диапазон измерения уровня - до 3 м; разрешающая способность датчика уровня - 0.1 мм; основная погрешность измерения уровня $-0.5 \%$; рабочий диапазон температур $-0 \ldots+80{ }^{\circ} \mathrm{C}$; габаритные размеры -51 х3180 мм; масса -3.5 кг.

Глубоководный зонд [Калинов и др., 2000, 2012]. Вариации температуры и электропроводности воды, измеряемые в стволе пьезометрической скважины, характеризуют физико-химическое состояние подземных вод. Для их измерения используется глубоководный измерительный зонд, который устанавливается в стволе скважины в диапазоне глубин 10-200 м от поверхности земли. В скв. Ю3-5 зонд находился на глубине 97 м ниже оголовка, в скв. Е-1 - на глубине 20 м. 
На рис. 4 представлены функциональная схема зонда $(a)$ и конструкция датчика электропроводности (б) [Калинов и др., 2012].

a

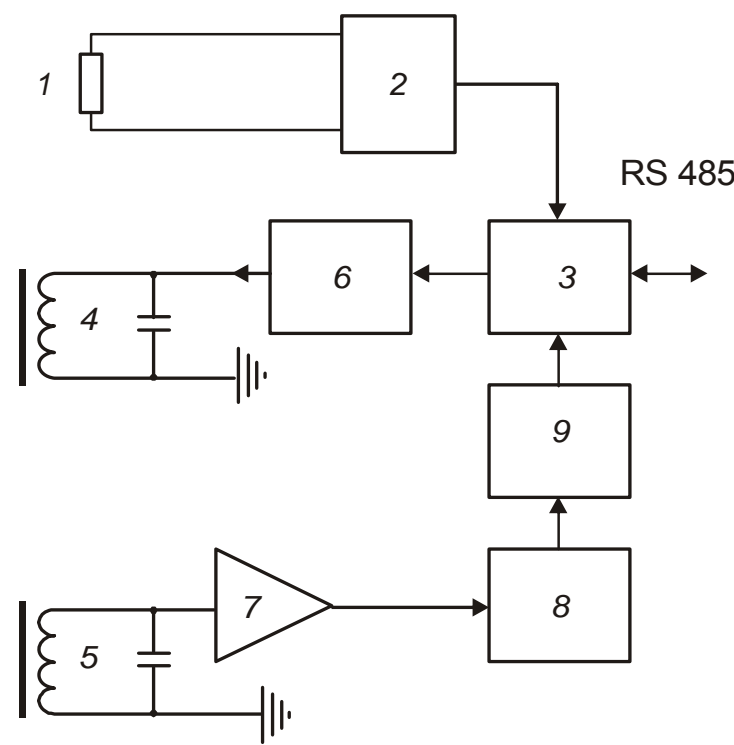

6

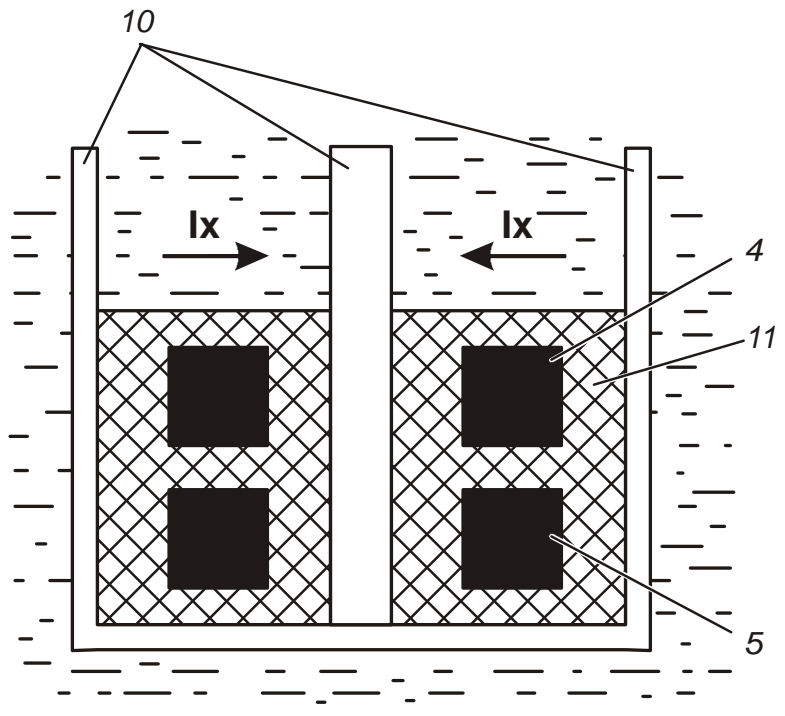

Рис. 4. Глубоководный зонд: $a$ - блок-схема; $\sigma$ - конструкция датчика электропроводности (пояснения см. в тексте)

В качестве датчика температуры ( 1 на рис. $4, a)$ используется платиновое сопротивление Platinum RTDs 1000, подключенное к АЦП (2). В качестве АЦП используется 16-разрядный малошумящий сигма-дельта преобразователь с дифференциальным входом AD7788. Управление устройством выполняется встроенным микропроцессором 3 средствами SPI-интерфейса. Расчет температуры производится микропроцессором по специальному алгоритму с погрешностью не более $0.5 \%$.

Датчик электропроводности основан на индукционном способе и представляет собой систему двух соосно расположенных тороидальных катушек индуктивности (4 и 5 на рис. 4, б), охваченных общей петлей связи в виде элементов корпуса датчика 10 и жидкостного проводника контролируемой водной среды. Для повышения электрической чувствительности и снижения электрических помех, обусловленных индуктивными и емкостными связями, приемная катушка находится в незамкнутом экране. Генератор 6 подает переменное напряжение амплитудой 10 В на излучающую катушку 5 . Электромагнитное поле вихревых токов возбуждает в приемной катушке 4 ЭДС с величиной? пропорциональной электропроводности жидкости, в которую погружен датчик. ЭДС с катушки поступает на усилитель 7, детектор 8 и через АЦП 9 - на микропроцесcop. Схема формирует постоянное напряжение, которое прямо пропорционально электропроводности в диапазоне от $10 \mathrm{MB}$ до $3.3 \mathrm{~B}$. У датчика проводимости фактически отсутствуют электроды и электрический контакт с жидкостью, что позволяет использовать его в полевых условиях и на больших глубинах. Оцифрованные значения температуры и проводимости по запросу передаются в блок сбора информации.

Блок сбора информащии. Центральным узлом измерительного комплекса является блок сбора информации (БСИ), который представляет собой специализированный регистратор данных (логгер), расположенный на поверхности над оголовком скважины (рис. $2, a, 8)$. Программное управление логгером и специализированными датчиками осуществляется микропроцессором серии AVR типа ATMEGA128. 
В исходном состоянии микропроцессор БСИ всегда находится в “спящем” режиме и потребляет от источника напряжением +12 В не более 70 мкА. При воздействии сигналов от кнопок управления выносного индикатора или от минутных импульсов встроенных часов процессор активизируется. Логгер производит опрос измерительных датчиков, заносит результаты в накопитель данных, осуществляет сеансы связи и переходит в режим пониженного энергопотребления. Информация с уровнемера, датчиков электропроводности и температуры воды по специальному кабелю (интерфейс RS 485) передается на микропроцессор БСИ. Температура воздуха и атмосферное давление измеряются датчиками, установленными на плате БСИ и подключенными к его микропроцессору. Опрос всех датчиков может производиться с заданной периодичностью от 5 минут до 1 часа.

Микропроцессор БСИ контролирует напряжение батареи питания и токи потребления в измерительных каналах с помощью встроенных АЦП. БСИ обеспечивает минимизацию электропотребления всеми устройствами и защиту от короткого замыкания в измерительных каналах. В КФ ФИЦ ЕГС РАН информация с измерительных станций Кедр-ДМ передается по каналам сотовой связи. Управление модемами осуществляет микропроцессор средствами интерфейса RS 232 (конвертор UART - RS 232). Для сотовой связи применяются модемы TC65 (Terminal фирмы Siemens), которые работают в диапазоне GSM 850/900/1800/1900 МГц. Пакетная передача данных осуществляется с использованием модема с встроенными средствами GPRS. Передача информации осуществляется один раз в час.

\section{Результаты наблюдений}

Начало наблюдений с использованием описанных выше технических средств на скв. Ю3-5 - 23.09.2010 г., на скв. Е-1 - 15.09.2011 г. Интервал измерения параметров составлял 5 мин; передача данных в КФ ФИЦ ЕГС РАН осуществлялась один раз в час по каналам сотовой связи.

Описание методики обработки данных уровнемерных наблюдений для выделения вариаций уровня воды, связанных с влиянием сейсмичности (гидрогеосейсмических вариаций), приводится в [Копьлова и дp., 2007], а также в других публикациях авторов (см. http://emsd.ru/lgi/result/hydro). Обработка данных проводилась ежедневно, что позволяло диагностировать гидрогеосейсмические вариации параметров режима подземных вод в режиме близком к реальному времени.

В 2013 г. на Камчатке произошла серия сильных землетрясений с магнитудами 6 и более [Сильные..., 2014]. Наиболее значительными событиями были землетрясение 28 февраля, $M_{w}=6.8$, произошедшее в акватории Тихого океана, и мантийное землетрясение магнитудой $M_{w}=8.324$ мая в Охотском море (см. рис. 1, таблица). В результате этих землетрясений были зарегистрированы разнообразные изменения уровня и физико-химических параметров подземных вод в режиме, близком к реальному времени [Сильные..., 2014].

На рис. 5 представлены изменения уровня, температуры и электропроводности воды в скважине Ю3-5 в январе-июле 2013 г., в том числе краткосрочные гидрогеосейсмические вариации уровня воды (рис. $5,6,6$ ), вызванные сильными землетрясениями (см. таблицу) и зарегистрированные с использованием представленного выше измерительного комплекса.

После вступления сейсмических волн от землетрясения 28 февраля в течение 45 мин происходило повышение уровня с амплитудой 2.2 см (рис. 5, б). После землетрясения 24 мая наблюдалось повышение уровня в течение 20 мин с амплитудой $7.3 \mathrm{~cm}$ (рис. 5, в). Такие эффекты могли быть вызваны наложением косейсмических скачков 

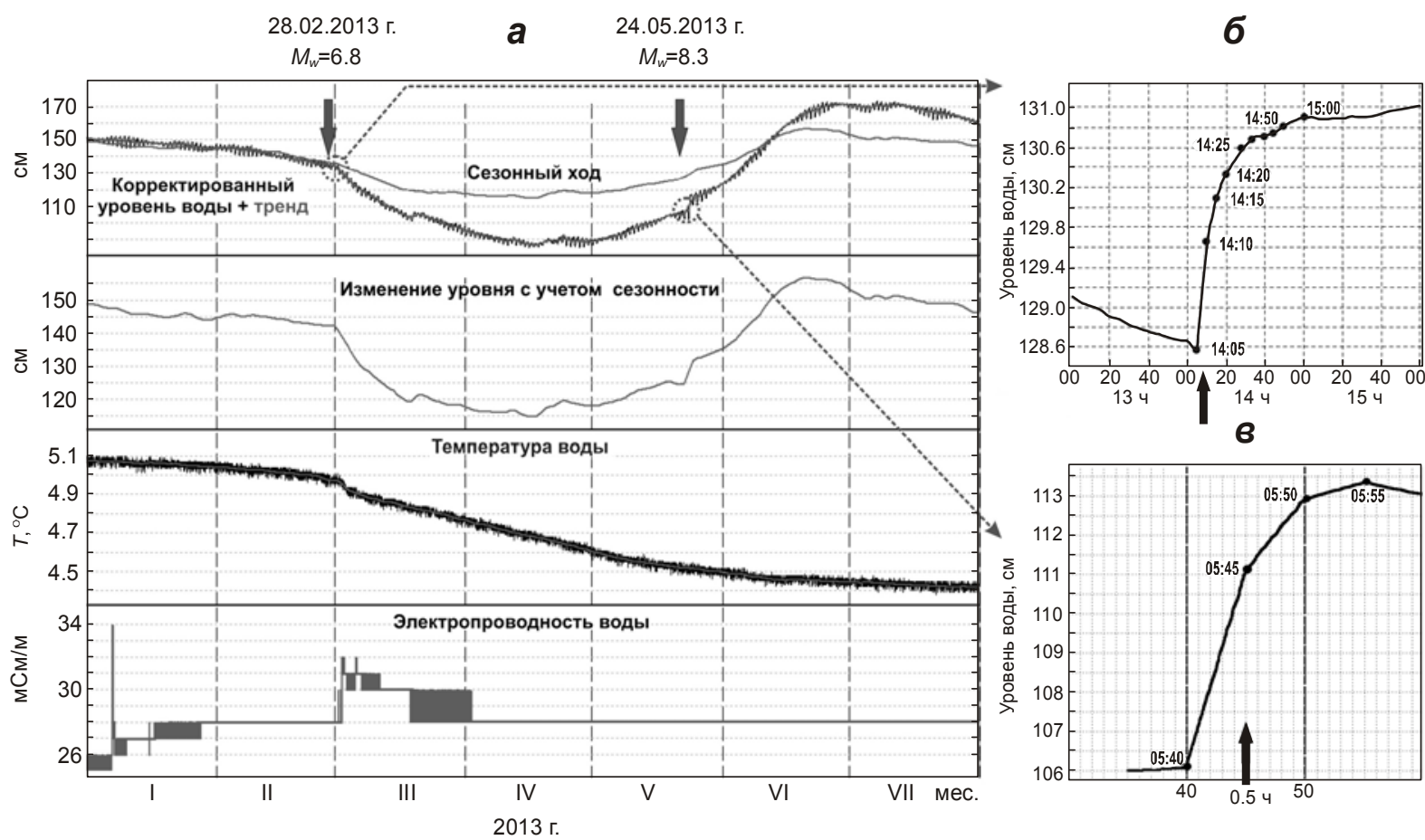

Рис. 5. Изменения уровня, температуры и электропроводности воды в скважине Ю3-5 с 1 января по 1 августа 2013 г., включающие ко- и постсейсмические вариации вследствие землетрясений 28 февраля и 24 мая 2013 г. (а, показаны стрелками). Детальные данные 5-минутных наблюдений во время вступления сейсмических волн от землетрясения 28.02.2013 г. (б) и Охотоморского землетрясения 24.05.2013 г. (в)

повышения уровня вследствие объемного сжатия водовмещающих пород при образовании разрывов в очагах землетрясений и кратковременных импульсов повышения порового давления в системе “скважина - водовмещающая порода" при прохождении сейсмических волн [Сильные..., 2014].

После землетрясения 28 февраля в изменениях среднечасовых значений уровня воды наблюдалось его интенсивное понижение (рис. $5, a$ ), которое развивалось до середины апреля 2013 г. Амплитуда понижения уровня в течение 1.5 мес. составила 35 см. Следует отметить, что эффект постсейсмического понижения уровня воды наблюдался ранее в скв. Ю3-5 лишь однажды, после Кроноцкого землетрясения 5 декабря 1997 г., $M_{W}=7.8$. В случае Кроноцкого землетрясения понижение уровня с амплитудой около 1 м продолжалось три месяца [Копьлова, 2006а].

После землетрясения 24 мая наблюдалось повышение уровня воды (рис. 5, $a$ ), которое развивалось до конца июня. Амплитуда повышения уровня составила $24 \mathrm{~cm}$.

В среднечасовых изменениях уровня воды, очищенных от влияния атмосферного давления, земных приливов и сезонных вариаций (рис. $5, a$ ), не обнаружены аномалии в диапазоне периодов сутки-десятки суток перед обоими землетрясениями. Это указывает на отсутствие значимых проявлений процессов подготовки этих сейсмических событий в изменениях уровня воды в скв. Ю3-5 в течение суток-первых месяцев перед землетрясениями 28 февраля и 24 мая 2013 г.

На рис. 5, а также представлены изменения температуры и электропроводности воды в скв. Ю3-5. После землетрясения 28.02.2013 г. произошло заметное понижение температуры воды амплитудой $0.6^{\circ} \mathrm{C}$ и повышение электропроводности на $4 \mathrm{MCM} / \mathrm{M}$. Такие изменения физико-химических параметров подземных вод можно отнести к постсейсмическим вариациям в режиме этой скважины. Резкое повышение электропроводности воды амплитудой 6 мСм/м было зарегистрировано 7 января примерно за 
8 недель до землетрясения (рис. $5, a$ ). Возможное значение этого эффекта для прогноза землетрясений можно будет оценить по результатам дальнейших наблюдений.

В скв. Е-1 перед землетрясением 28.02.2013 г. проявлялся гидрогеодинамический предвестник в течение времени с 16 января по 27 февраля (рис. 6). Гидрогеодинамический предвестник в форме понижения уровня воды с повышенной скоростью в скв. Е-1 ранее был описан в [Копылова, 2001; Копьллова, Болдина, 2012; и др.]. Особенностями этого вида предвестника являются: 1) его относительно регулярная повторяемость перед землетрясениями с $M \geq 5.0$ на расстояниях до 350 км (более $70 \%$ случаев), что позволяет использовать его для прогнозирования сильных местных землетрясений; 2) увеличение связи предвестника и землетрясений с ростом их магнитуды [Копылова, 2001], указывающее на то, что перед более сильными сейсмическими событиями предвестник проявляется с большей регулярностью.

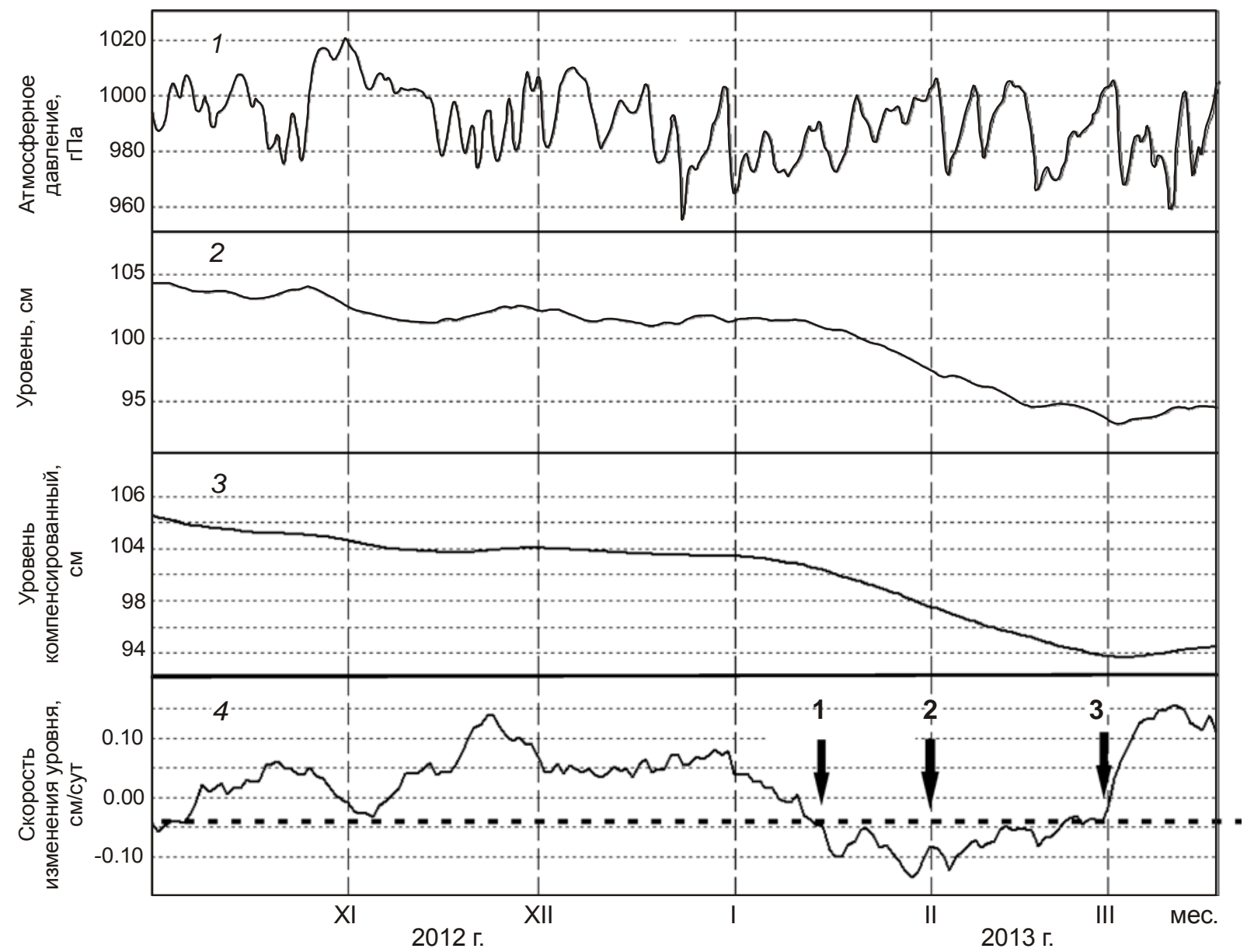

Рис. 6. Изменения уровня воды в скважине Е-1 с 01.10 .2012 г. по 18.03.2013 г.: 1 и 2 - данные 5 -минутной регистрации атмосферного давления и уровня воды, 3 - среднесуточные изменения уровня воды с компенсированными баровариациями, 4 - суточная скорость изменения уровня воды с учетом скорости нисходящего тренда. На графике 4 стрелками показаны: 1 16.01.2013 г., начало проявления гидрогеодинамического предвестника; 2 - 01.02.2013 г., дата подачи прогнозного заключения в КФ РЭС; 3 - 28.02.2013 г., дата землетрясения. Горизонтальная пунктирная линия - пороговое значение суточной скорости изменений уровня воды

С использованием этого вида предвестника по текущим данным уровнемерных наблюдений на скв. Е-1 с 2002 г. осуществляется оценка опасности возникновения сильных землетрясений в районе г. Петропавловска-Камчатского с предоставлением 
прогнозных заключений в Камчатский филиал Российского экспертного совета по прогнозу землетрясений, оценке сейсмической опасности и риска (КФ РЭС). На основе этого предвестника 01.02.2013 г. Г.Н. Копыловой был подготовлен среднесрочный прогноз о повышенной вероятности возникновения сильного землетрясения на Камчатке, который был передан в КФ РЭС (рис. 6). В прогнозном заключении от 01.02.2013 г. указывалось, что “в течение времени 1-2 мес. повышена вероятность возникновения землетрясения с $M \geq 5.0$ на расстоянии до 350 км от скважины”. В заключении также были приведены оценки надежности прогноза для землетрясений различных значений магнитуды, основывающиеся на результатах ретроспективного анализа проявлений гидрогеодинамического предвестника за период многолетних наблюдений [Копылова, Сизова, 2012]: “вероятность события с $M \geq 5.0 P=0.45$, прогнозная эффективность предвестника $I=1.4$; вероятность события с $M \geq 5.9 P=0.73$, прогнозная эффективность предвестника $I=2.2$ ". В этом заключении под вероятностью события $P$ понимается отношение числа землетрясений в указанном диапазоне магнитуд, произошедших на расстоянии до 350 км от скважины, которым предшествовало проявление предвестника, к общему числу таких событий. Величина прогнозной эффективности I оценивалась по [Гусев, 1974] и показывает во сколько раз использование данного предвестника улучшает прогноз по сравнению со случайным угадыванием.

Произошедшее 28 февраля землетрясение с $M_{W}=6.8$ на расстоянии 290 км от скважины соответствовало прогнозу от 1 февраля по магнитуде, времени и местоположению. Поэтому прогноз, поданный 01.02.2013 г. в КФ РЭС, является успешным как по авторским оценкам, так и по заключению КФ РЭС [Сильные..., 2014, с.152].

Поданный в КФ РЭС 01.02.2013 г. прогноз землетрясения по данным наблюдений за вариациями уровня воды в скв. Е-1 является также вероятностным, так как сопровождался оценками вероятности его реализации в отношении событий с различными величинами магнитуды. Это стало возможным благодаря выполненной систематизации данных о проявлении гидрогеодинамического предвестника в сопоставлении с произошедшими землетрясениями для периода многолетних (1987-2012 гг.) наблюдений на скв. Е-1. Тем самым было обеспечено его параметрическое описание [Копьлова, 2001; Копьлова, Сизова, 2012].

После землетрясения 28.02.2013 г. в скв. Е-1 в течение 1.5 мес. наблюдалось постсейсмическое повышение и последующее восстановление уровня воды. В течение двух суток после землетрясения в изменениях электропроводности фиксировалось слабое ее повышении с амплитудой 2 мСм/м. Ретроспективно было выявлено повышение электропроводности воды на 2 мСм/м 12.01.2013 г.

Изменения уровня воды в скв. Е-1 в период землетрясения 28 февраля: понижение с повышенной скоростью в течение 44 сут перед землетрясением и его повышение с амплитудой около 2 см после землетрясения (рис. 6) является типичным для периодов возникновения сильных $(M \geq 6.6)$ местных землетрясений на расстояниях до первых сотен километров [Kопылова, 2001; 2010]. В изменениях уровня воды в скв. Е-1 было зарегистрировано последовательное проявление гидрогеодинамического предвестника, который сменился после землетрясения постсейсмическим повышением, что согласуется с установленной ранее закономерностью изменения уровня воды в этой скважине при таких землетрясениях.

По данным регистрации физико-химических параметров подземных вод в скв. Е-1 с использованием глубинного зонда было обнаружено слабое повышение электропроводности воды амплитудой 1-2 мСм/м в течение двух суток после землетрясения (постсейсмический эффект). В изменениях температуры воды гидрогеосейсмические вариации не проявлялись. 


\section{Заключение}

Созданная в КФ ФИЦ ЕГС РАН система наблюдений на скважинах с использованием аппаратурных комплексов Кедр-ДМ [Кедр-ДМ..., 2007] производства ООО "Полином", г. Хабаровск позволяет диагностировать гидрогеосейсмические вариации в изменениях уровня и физико-химических параметров подземных вод в режиме, близком к реальному времени. Наличие таких данных позволяет осуществлять углубленное изучение регистрируемых гидрогеосейсмических вариаций в изменениях физико-химических параметров подземных вод для оценки влияния сейсмичности на состояние подземных вод, включая процессы подготовки сильных землетрясений. При этом методология изучения гидрогеосейсмических вариаций параметров подземных вод должна включать их систематизацию и типизацию в сопоставлении с данными о вызвавших их землетрясениях с учетом локальных гидрогеологических условий.

Опыт наблюдения гидрогеосейсмических вариаций уровня, температуры и электропроводности воды с использованием аппаратурного комплекса Кедр-ДМ-У в двух пьезометрических скважинах в периоды сильных землетрясений 2013 г. показал надежность всех его элементов и высокую точность регистрации вариаций уровня воды с использованием ультразвукового скважинного уровнемера.

Вместе с тем, глубоководный зонд, входящий в состав оборудования (см. рис. 2,8$)$, нуждается в доработке за счет обеспечения более высокой разрешающей способности датчика электропроводности воды. В настоящее время его разрешающая способность составляет 1 мСм/м, что является недостаточным для уверенного выделения гидрогеосейсмических вариаций в изменениях электропроводности подземной воды. При регистрации вариаций уровня воды также желательно осуществлять измерения с частотой не менее 1-10 Гц, особенно во время прохождения сейсмических волн, как это обеспечивается за рубежом (в Японии, США, в Китае, Израиле и других странах) при проведении аналогичных наблюдений [Wang, Manga, 2010].

В изменениях параметров подземных вод в скв. Ю3-5 (см. рис. 5) обнаружены гидрогеосейсмические вариации, вызванные воздействием сейсмических волн от землетрясения 28.02.2013 г., в том числе понижение уровня и температуры воды, увеличение электропроводности с максимальной амплитудой 4 мСм/м. Продолжительность развития постсейсмических эффектов составила 1-2 мес. За 8 недель до землетрясения было зафиксировано повышение электропроводности воды на 6 мСм/м.

По данным уровнемерных наблюдений в скв. Е-1 осуществлен успешный прогноз землетрясения 28.02.2013 г., $M_{W}=6.8$ с временем упреждения 4 нед. Прогноз сопровождался вероятностной оценкой его реализации, основанной на ретроспективном изучении (по данным многолетних наблюдений связи) гидрогеодинамического предвестника в изменениях уровня воды с произошедшими землетрясениями и его параметрическом описании.

\section{Благодарности}

Исследование выполнено в рамках плана научно-исследовательских работ ФИЦ ЕГС РАН по темам: "Проведение непрерывного сейсмологического, геофизического и геодинамического мониторинга на глобальном, федеральном и региональном уровнях, разработка и внедрение новых технологий обработки и системного анализа больших объемов сейсмологических и геофизических данных" (АААА-А16-116070550057-7), "Комплексное исследование предвестников сильных землетрясений и развитие методик прогнозирования сейсмической обстановки в сейсмоопасных регионах" (AAAA-A16116070550059-1). 
Авторы выражают благодарность сотрудникам ООО “Полином" (г. Хабаровск) кандидату технических наук Г.А. Калинову и Д.Г. Калинову за полезные консультации по техническим вопросам установки оборудования на скважинах и его эксплуатации.

\section{Литература}

Гусев А.А. Прогноз землетрясений по статистике сейсмичности // Сейсмичность и сейсмический прогноз, свойства верхней мантии и их связь с вулканизмом на Камчатке. Новосибирск: Наука, 1974. С.109-119.

Калинов Г.А., Лысаков А.В., Римлянд В.И. Способ ультразвукового измерения уровня жидкости: Патент 2156962 РФ. 2000 г.

Калинов Г.А., Мигунов Д.С., Римлянд В.И. Оценка влияния шумов на фазовый способ определения момента прихода акустических импульсов // Вестник ТОГУ. 2009. № 1. Вып. 12. C.275-282.

Калинов Г.А., Лысаков А.В., Римлянд В.И. и др. Автоматизированная система сбора гидрологической информации // Измерительная техника. 2012. № 2. Вып. 32. С.92-99.

Кедр-ДМ. Комплекс для мониторинга ГГд поля с телеметрической передачей данных. Руководство по эксплуатации. ТДКП. 110879.004 РЭ. Хабаровск, 2007. 57 с.

Копылова Г.Н. Изменения уровня воды в скважине Елизовская-1, Камчатка, вызванные сильными землетрясениями (по данным наблюдений в 1987-1998 гг.) // Вулканология и сейсмология. 2001. № 2. С.39-52.

Копылова Г.Н. Изменения уровня воды в скважине Ю3-5, Камчатка, вызванные землетрясениями // Вулканология и сейсмология. 2006а. № 6. С.52-64.

Копылова Г.Н. Сейсмичность как фактор формирования режима подземных вод // Вестник КРАУНЦ. Серия науки о Земле. 2006б. № 1. Вып. 7. С.50-66.

Копылова (Грии) Г.Н. Эффекты сейсмичности в режиме подземных вод (на примере Камчатского региона): Автореф. дис. ... докт. геол.-мин. наук. Петропавловск-Камчатский, 2010. $36 \mathrm{c}$.

Копылова Г.Н., Болдина С.В. О связи изменений уровня воды в скважине Е-1, Восточная Камчатка, с активизацией вулкана Корякский в 2008-2009 гг. и сильными $(M \geq 5)$ землетрясениями // Вулканология и сейсмология. 2012. № 5. С.41-54.

Копылова Г.Н., Сизова Е.Г. О предвестнике землетрясений, проявляющемся в изменениях уровня воды в скважине Е-1, Камчатка // Вулканизм и связанные с ним процессы. Матер. конф., посвященной Дню вулканолога. Петропавловск-Камчатский: ИВиС ДВО РАН, 2012. C.116-125.

Копылова Г.Н., Сугробов В.М., Хаткевич Ю.М. Особенности изменения режима источников и гидрогеологических скважин Петропавловского полигона (Камчатка) под влиянием землетрясений // Вулканология и сейсмология. 1994. № 2. С.53-70.

Копылова Г.Н., Куликов Г.В., Тимофеев В.М. Оценка состояния и перспективы развития гидрогеодеформационного мониторинга сейсмоактивных регионов России // Разведка и охрана недр. 2007. № 11. С.75-83.

Лугуманов М.Г., Аметшин Р.М. Высокочувствительный датчик электропроводности бурового раствора // Научно-технический вестник “Каротажник”. 2003. С.111-112.

Римлянд В.И., Калинов Г.А., Казарбин А.В. Автоматизированная система измерения уровня жидкости в резервуарах // Изв. вузов. Приборостроение. 2000. Т. 43, № 3. С.47-50.

Сильные камчатские землетрясения 2013 года / Под ред. В.Н. Чеброва. Петропавловск-Камчатский: Холд. Комп. "Новая книга", 2014. 252 с.

Wang C.-Y., Manga M. Earthquakes and Water. Heidelberg Dordrecht London New York: Springer, 2010. 225 p. DOI: 10.1007/978-3-642-00810-8.

Сведения об авторах

КОПЫЛОВА Галина Николаевна - доктор геолого-минералогических наук, доцент, заведующая лабораторией, Камчатский филиал Федерального исследовательского центра "Единая 
геофизическая служба РАН”. 683006, Петропавловск-Камчатский, бульвар Пийпа, д. 9. Тел.: 8(4152) 43-18-49. E-mail: gala@emsd.ru

БОЛДИНА Светлана Васильевна - кандидат геолого-минералогических наук, научный сотрудник, Камчатский филиал Федерального исследовательского центра “Единая геофизическая служба РАН”. 683006, Петропавловск-Камчатский, бульвар Пийпа, д. 9. Тел.: 8(4152) 43-18-35. E-mail: boldina@emsd.ru

СМИРНОВ Анатолий Александрович - начальник сектора, Камчатский филиал Федерального исследовательского центра "Единая геофизическая служба РАН". 683006, ПетропавловскКамчатский, бульвар Пийпа, д. 9. Тел.: 8(4152) 43-18-18. E-mail: asmirnov@emsd.ru

ЧУБАРОВА Елена Геннадьевна - инженер-исследователь, Камчатский филиал Федерального исследовательского центра "Единая геофизическая служба РАН”. 683006, Петропавловск-Камчатский, бульвар Пийпа, д. 9. Тел.: 8(4152) 43-18-54. E-mail: sizel@emsd.ru

\title{
An experience in registration of water level and physical and chemical parameters of ground waters in the wells due to strong earthquakes (on the example of Kamchatka)
}

\author{
G.N. Kopylova, S.V. Boldina, A.A. Smirnov, E.G. Chubarova \\ Kamchatka Branch, Geophysical Survey RAS, Petropavlovsk-Kamchatsky, Russia
}

\begin{abstract}
The paper describes the hardware complex for registration of water level, temperature, electrical conductivity of ground water and meteorological parameters (atmospheric pressure, air temperature) with frequency measurement from 5 minutes to one hour produced by a LLC "Polynom", Khabarovsk, installed in the wells in Kamchatka. With the use of this equipment, we registered different variations of measured parameters in groundwater in wells UZ-5 and E-1 due to strong earthquakes 2013, which occurred on February 28, $M_{W}=6.8$ and 24 May, of $M_{W}=8.3$. A description is given of the variations due to earthquakes and their systematization taking into account of the mechanisms of seismic impact on the state of the system "well - water-saturated rock".
\end{abstract}

Keywords: well, water level, electrical conductivity, hardware complex, earthquake, Kamchatka. 